\title{
The Effect of Some Antioxidants Compounds on Enzymatic and Nonenzymic Browning of Quince Juice During Thermal Treatment
}

\author{
Aya I. Rashan ${ }^{1 *}$, Omar Y. Al-abbasy ${ }^{2}$ \\ ${ }^{1,2}$ Department of Chemistry, College of Education for Pure Sciences, University of Mosul, Mosul, Iraq \\ E-mail: ${ }^{1 *}$ ayaa.rashan1994@gmail.com, ${ }^{2}$ chem.omar1978@uomosul.edu.iq
}

(Received May 23, 2020; Accepted August 16, 2020; Available online December 01, 2020)

DOI: 10.33899/edusj.2020.127190.1078, (c) 2020, College of Education for Pure Science, University of Mosul.

This is an open access article under the CC BY 4.0 license (http://creativecommons.org/licenses/by/4.0/).

\begin{abstract}
Enzymatic browning by tyrosinase and nonenzymatic browning (Maillard reaction) are responsible for producing new compounds which contributes considerably to the undesirable of aroma, taste and colour in food. In this study, tyrosinase activity and browning intensity in quince juice were inhibited by treating them with antioxidant compounds vanillin, glutathione and melatonin as compared to the control. The maximum inhibition percentage of Tyrosinase were 83, 68.8 and $90.3 \%$ and the maximum inhibitory effect of browning intensity were $13.9,9.7$ and $29.8 \%$ respectively.
\end{abstract}

For untreated quince juice which heated to 5 hours at $100{ }^{\circ} \mathrm{C}$, the results showed increasing in A294, Browning intensity (A420) and reducing power, as well as decreasing in reducing sugar, free amino group, phenolic compounds contents and inhibition percentage of lipid peroxidation. The decreasing of A294, browning intensity and increasing in reducing power were showed after treating with (10mM) vanillin and (8mM) glutathione compared to control. Conversely to glutathione, the addition of vanillin to quince juice revealed increasing in inhibition percentage of lipid peroxidation, reducing sugar and phenolic contents and decreasing in free amino acid content compared to control. Inhibition Mode of tyrosinase by melatonin was non-competitive. The $\mathrm{K} m$ value remained constant $(1.96 \mathrm{mM})$, while Vmax reduced from 228.13 to $114.06 \mathrm{U}^{\mathrm{ml}}{ }^{-1} \cdot \mathrm{min}^{-1}$. Inhibition constant $\mathrm{K} i$ value was $6.9 \mathrm{mM}$.

Keywords:_Tyrosinase , maillard reaction,glutathione, melatonin, Quince

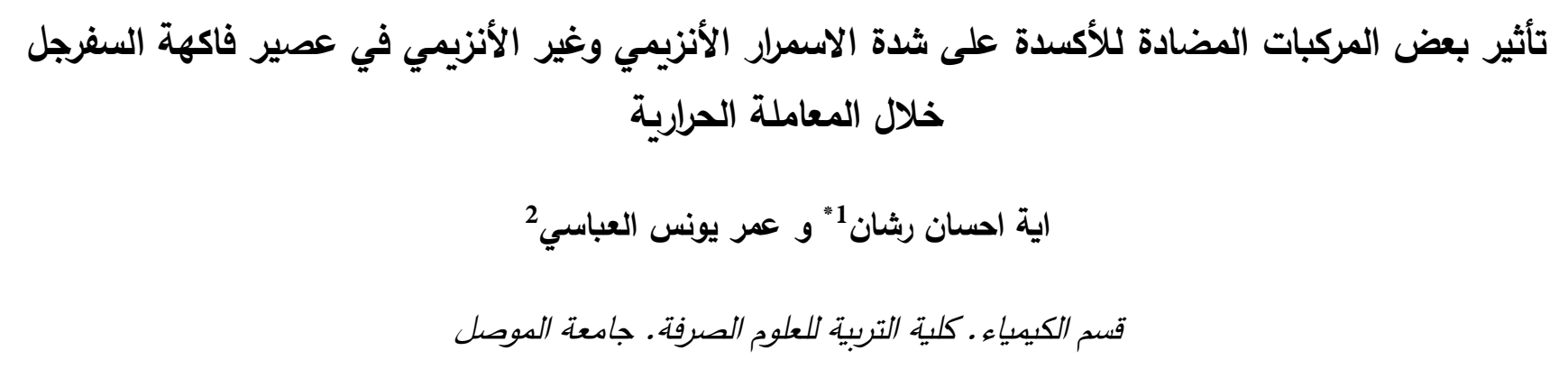

الخلاصة

ان الاسمرار الانزيمي الحاصل بواسطة انزيم التايروسينيز والاسمرار غير الانزيمي (تفاعل ميلارد) هما المسؤولان عن انتاج مركبات جديدة والتي تساهم الى حد بعيد في تكوين نكهة ولون وطعم غير مرغوب به في الاغذية ـ في هذه الدراسة ثبطت فعالية انزيم 


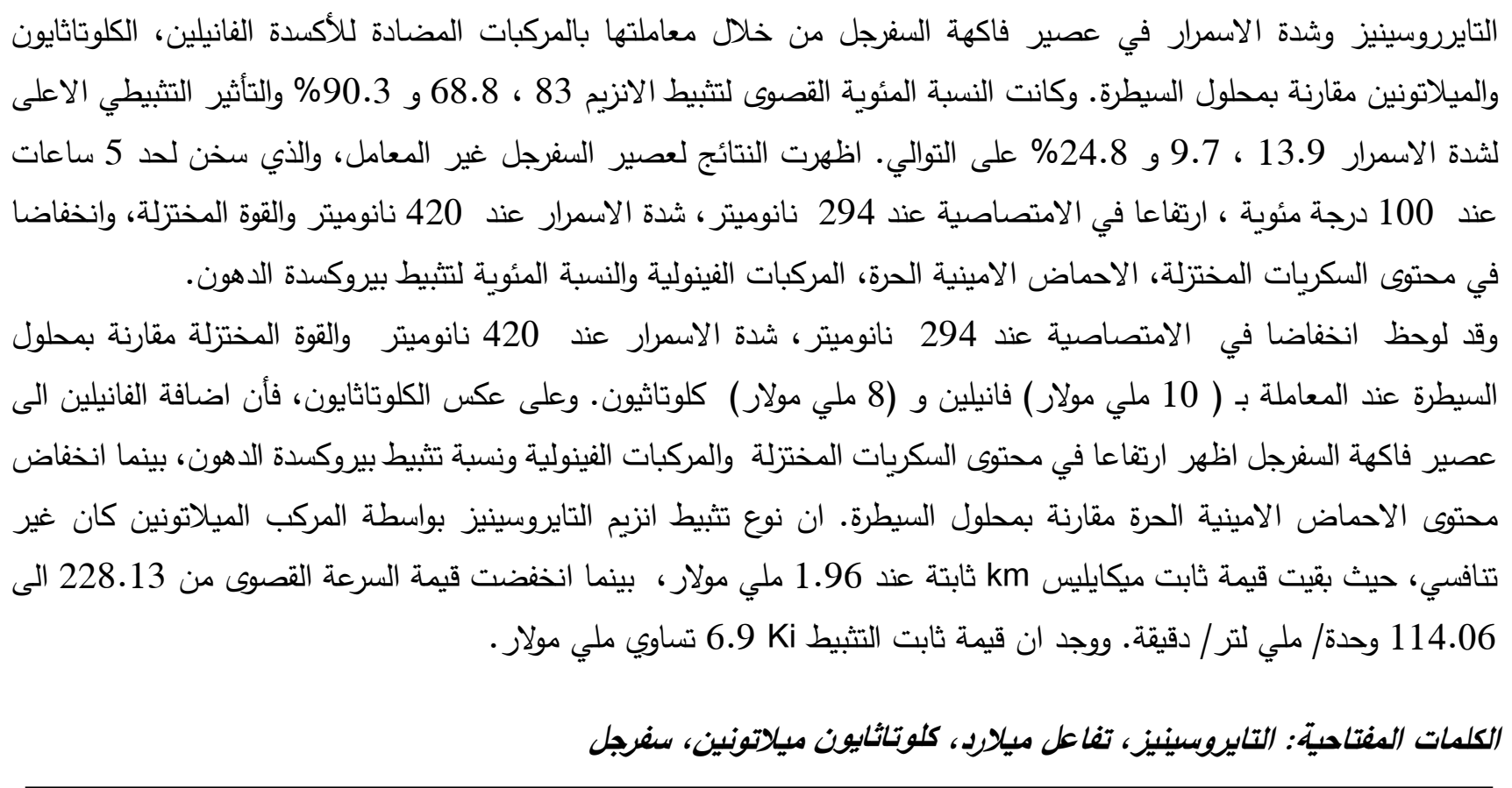

\section{Introduction:}

Quince (Cydonia oblonga Miller) fruit is a valuable dietary product belongs to family Rosaceae, which contains healthy famous fruits such as apples and pears. On maturing, the abundant hairs which cover the peel were disappeared and this stage is extremely required for processing it into candy, jam, jelly and cakes (1). The fruit contains good quantity of water, carbohydrates, proteins, tannins, organic acids and crude fibers The fruit is a worthy source of vitamins such as A and B and rich in vitamin C. It also contains potassium, calcium, phosphorous and has very low amounts of fat (2-5). The astringency and sweetness of quince by reason of it is rich in glucose, fructose and sorbitol and also in phytic, malic, citric and quinic acids (6-7). Quince fruits are described moderately higher quantity of amino acids (8), as well as antioxidant and phenolic compounds (9).

Quince has a number of important health benefits such as expectorant, carminative and anticancer (10), being also used for the treatment of cold, influenza, migraine (11) and conjunctivitis (12). It has hypoglycemic action, antimicrobial, anti-allergic, anti-inflammatory and antiulcer and act as a boost for heart and brain(13-16)

Two forms of browning are usually detected in fruits and vegetables, namely enzymatic and nonenzymatic browning. Enzymatic browning is produced via hydroxylated of monophenolic compounds to o-diphenols that were oxidized to o- quinones by polyphenoloxidases (also known as tyrosinase, phenolase, cresolase or catecholase). Non-enzymatic browning reactions include degradation of ascorbic acid, Lipid peroxidation and Sugar caramelization as well as reactions that are initiated by a 
condensation of reducing sugars, with compounds which contain a free amino group, as amino acids, peptide and proteins. This reaction is also well-known as Maillard reaction (17-19), which contributes significantly to the undesirable appearance, aroma, taste and colour (20).

Likewise to reducing carbohydrates, ascorbic acid may also react with amino compounds to form brown pigments and accelerate Maillard browning (21-22). These reactions take place through, cookery, storage and processing of foods. But thay may be desirable during manufacturing of baking of bread, tea, beer and coffee. (23).

Recently, various strategies have been attempted for controlling Maillard reactions. Natural compounds such as polyphenols, amino acid, peptide and vitamins, as well as enzymes were used for targeting reactive sites, intermediates, or/and products (24). This controlling is very important not only to improve flavour, odour and colour, but because of likely toxicity of the products. Maillard reactions can be inhibited using different systems of the reactants or removing one of the reacting materials (25), or by using chemical inhibitors (26). Aminoguanidine was one of the compounds that has the ability of inhibiting Maillard reaction (27) by trapping $\alpha$-dicarbonyls mechanism (28-29).

\section{Experimental}

\section{Preparation of juice:}

Healthy quince fruits were harvested in November from Mosul, Iraq, and used in this research. Quince (80g) were washed, peeled, cut and blended with $100 \mathrm{ml}$ phosphate buffer, filtered through muslin cloth and centrifuged at $3220 \mathrm{xg}$ for 15 minutes respectively to get a clear juice(30).

\section{Inhibitors preparation:}

The concentrations (2 to $10 \mathrm{mM}$ intervals 2) of Vanillin (VAN), Glutathione (GSH), and Melatonine (MEL) were prepared and used as inhibitors for tyrosinase and MRPs.

\section{Tyrosinase assay:}

By using tyrosine as substrate, tyrosinase activity was spectrophotometrically measured at $\lambda=280 \mathrm{~nm}$ according to the the Worthington manual Decker (1977) method. One unit of tyrosinase activity was defined as the amount of enzyme that caused a change in absorbance of 0.001 per minute at $25^{\circ} \mathrm{C}$ and $\mathrm{pH}=6.8(31)$. 


\section{The effect of inhibitors on tyrosinase activity and browning intensity in juice :}

To four millilitre of clear juice, one milliliter of individual inhibitors was added. The mixtures were used to determine tyrosinase activity at $280 \mathrm{~nm}$ and browning intensity at $420 \mathrm{~nm}$. A control container was kept without inhibitors. The inhibition concentration $\left(\mathrm{IC}_{50}\right)$ values of melatonin were determined by following equation: $\mathrm{IC}_{50}=50-\mathrm{b} / \mathrm{a} . \boldsymbol{a}$ and $\boldsymbol{b}$ are slope and intercept respectively of the straight line

\section{The effect of time on tyrosinase activity and browning intensity in juice:}

Three sets of six containers were used. In each one, $4 \mathrm{ml}$ of juice and $1 \mathrm{ml}$ individual concentration of VAN $(10 \mathrm{mM})$, MEL $(10 \mathrm{mM})$ and GSH $(8 \mathrm{mM})$ were added successively and the sixth container was kept as a control. Tyrosinase activity and browning intensity at 420nm were measured at 0-120 minutes (30).

\section{Inhibition type of tyrosinase by melatonin:}

The inhibition mode of purified tyrosinase was planned using melatonin (5.9 mM). After incubating $0.5 \mathrm{ml}$ of purified enzyme with $1 \mathrm{ml}$ of inhibitor, the activity was followed using $(0.6-10 \mathrm{mM})$ of Ltyrosine (30). The calculation of inhibition constant $(\mathrm{Ki})$ value was accomplished by the equation: $\mathrm{Km}^{\prime}=\mathrm{Km}(1+\mathrm{I} / \mathrm{Ki})(32)$.

\section{Preparation of Maillard reaction products (MRPs):}

One millilitre individual above concentration of VAN and GSH was added to $4 \mathrm{ml}$ of Juice. To screwsealed tubes, the solution was conveyed, locked tightly and put in water bath at $100^{\circ} \mathrm{C}$. After heating the samples were taken every one hour, instantly cooled and analysed. All sapmles systems were prepared in dublicate. A control container was kept without inhibitors and the first measured hour without heating.

\section{Colourless intermediate and browning intensity measurement:}

The absorbance at $294 \mathrm{~nm}$ was measured to evaluat colourless intermediate. The browning intensity was estimated by monitoring the absorbance at $420 \mathrm{~nm}$. using a spectrophotometer (Shimadzu 1800 UV Spectrophotometer, Double Beam, Japan) (33). 


\section{Reducing Sugars content estimation:}

The amount of reducing sugars in juice was determined by Di-nitrosalicylic acid (DNSA). In tubes of $10 \mathrm{ml}, 1 \mathrm{~mL}$ of sample and $1 \mathrm{ml}$ of DNSA reagent are placed. Then tubes were heated at $100{ }^{\circ} \mathrm{C}, 5$ minutes., cooled and completed with $8 \mathrm{~mL}$ of distilled water.The absorbance was read at $540 \mathrm{~nm}$ by using Cecil 1100 spectrophotometer. The sample was replaced by distilled water in blank solution. The standard curve was prepared by using glucose (10-100mg/ml) (34).

\section{Free amino group content estimation:}

The determined of free amino group content was achieved by adding $0.2 \mathrm{ml}$ of ninhydrine reagent( $2 \mathrm{mg} / \mathrm{ml}$ in $20 \mathrm{mM}$ acetic acid - acetate buffer $\mathrm{pH} 5$ ) to $1 \mathrm{ml}$ of the sample. The solutions were heated 10 minutes at $100^{\circ} \mathrm{C}$ and cooled. By using a Cecil 1100 spectrophotometer, the absorbance at $570 \mathrm{~nm}$ was measured. The preparation of standard curve was carried out by using lysine $(5-50 \mathrm{mg} / \mathrm{ml})(35)$.

\section{Total phenolic compounds content estimation:}

Total phenolics were estimated according to method described by Anesini, Ferraro and Filip (2008)(36). $1 \mathrm{ml}$ of Cydonia oblonga Miller juice. was added to $5 \mathrm{~mL} 1 \mathrm{~N}$ Folin-Ciocalteu reagent. After 5 minutes, $4 \mathrm{~mL} \mathrm{7.5 \%} \mathrm{Na}_{2} \mathrm{CO}_{3}$ was added, and the reagent mixture was kept 60 minutes at room temperature. The quantification of phenolic compounds was spectrophotometrically determined by measuring the absorbance at $765 \mathrm{~nm}$, a gallic acid $(10-100 \mu \mathrm{g} / \mathrm{mL})$ was used for a standard curve.

\section{reducing power estimation:}

In glass tube $0.5 \mathrm{~mL}$ of sample was mixed with $0.5 \mathrm{~mL}$ of $\mathrm{pH} 6.6$ sodium phosphate buffer, $(0.2 \mathrm{M})$ and $0.5 \mathrm{~mL}$ of $\mathrm{K}_{4}\left[\mathrm{Fe}(\mathrm{CN})_{6}\right](1 \%)$. Half $\mathrm{ml}$ of trichloroacetic acid (TCA) (10\%) was added after incubating mixture at $50^{\circ} \mathrm{C}$ for 20 minutes then centrifuged 10 minutes at $805 \mathrm{xg} .0 .5 \mathrm{ml}$ of supernatant was treated with $0.5 \mathrm{ml}$ of distilled water and $200 \mu \mathrm{L}$ of $0.1 \% \mathrm{FeCl}_{3}$. The increasing in absorbance at $700 \mathrm{~nm}$. represents reducing power (37).

\section{The inhibition of lipid peroxidation:}

Lecithin $10.0 \mathrm{mg} / \mathrm{mL}$ was prepared in $10 \mathrm{mM}$ phosphate buffered saline, $\mathrm{pH} 7.4$ by stirring with magnetic stirrer (solution A). $2 \mathrm{ml}$ of concentrated hydrochloric acid, $15 \mathrm{~g}$ of TCA and $0.37 \mathrm{~g}$ of thiobarbituric acid were adjusted to $100 \mathrm{~mL}$ deionized water (solution $\mathrm{B}$ ). In glass tube $1 \mathrm{~mL}$ of solution A was added to $1 \mathrm{~mL}$ of $0.4 \mathrm{mM}$ ascorbic acid, $1 \mathrm{~mL}$ of $0.4 \mathrm{mM} \mathrm{FeCl}_{3}$ and $1 \mathrm{~mL}$ of sample then 
transferred to dark bath at $37^{\circ} \mathrm{C}$ for 1 hour. From solution $\mathrm{B} 2 \mathrm{~mL}$ was added, heated at $100^{\circ} \mathrm{C}$ for 15 minutes, cooled and centrifuged for 10 minutes at $1096 \mathrm{xg}$. The measure of absorbance at 532nm was investigated, and named as As. Deionized water was replaced for sample as blank (Ac). The inhibition percentage $(\%)=($ Ac-As $) / A c \times 100(38-39)$.

\section{Results and Discussion}

The effect of inhibitors on tyrosinase activity and browning intensity in juice:

Table $(1,2)$ explain the inhibition percentage of tyrosinase activity and browning intensity in quince juice treated with VAN, GSH and MEL by using different concentration and different time. The results indicate that the tyrosinase activity and browning intensity were reduced as compared to the control. The percentage of inhibition increased as the concentration of antibrowning agents increases (40). GSH and cinnamic acid were studied as anti-browning agent in apple juice. The browning reaction rate could be efficiently delayed due to the inhibition of PPO (31).

Table 1: Inhibitory effect of VAN,GSH and MEL on tyrosinase activity and browning intensity

\begin{tabular}{|c|c|c|c|c|c|c|}
\hline \multirow{2}{*}{$\begin{array}{c}\text { Inhibitors } \\
\text { conc.(mM) }\end{array}$} & $\begin{array}{c}\text { Inhibitory } \\
\text { effect of } \\
\text { browning } \\
\text { \% }\end{array}$ & $\begin{array}{c}\text { Tyrosinase } \\
\text { inhibiton } \\
\text { \% }\end{array}$ & $\begin{array}{c}\text { Inhibitory } \\
\text { effect of } \\
\text { browning } \\
\text { \% }\end{array}$ & $\begin{array}{c}\text { Tyrosinase } \\
\text { inhibiton } \\
\text { \% }\end{array}$ & $\begin{array}{c}\text { Inhibitory } \\
\text { effect of } \\
\text { browning \% }\end{array}$ & $\begin{array}{c}\text { Tyrosinase } \\
\text { inhibiton } \\
\%\end{array}$ \\
\hline Control & 0 & 0 & 0 & 0 & 0 & 0 \\
\hline 2 & 11.9 & 65.5 & 9 & 68 & 10.5 & 70.7 \\
\hline 4 & 12.5 & 70.3 & 9 & 64 & 9.2 & 70.5 \\
\hline 6 & 12.5 & 58.4 & 8.6 & 66.9 & 8.8 & 83.8 \\
\hline 8 & 12.9 & 32.5 & 9.7 & 68.6 & 12.9 & 20.5 \\
\hline 10 & 13.9 & 83.8 & 9 & 61.2 & 29.8 & 90.3 \\
\hline
\end{tabular}

Table 2: Time Effect on tyrosinase activity and Browning intensity using VAN,GSH and MEL

\begin{tabular}{|c|c|c|c|c|c|c|}
\hline \multirow{2}{*}{$\begin{array}{c}\text { Time } \\
\text { (min.) }\end{array}$} & $\begin{array}{c}\text { Inhibitory } \\
\text { effect of } \\
\text { browning \% }\end{array}$ & $\begin{array}{c}\text { Tyrosinase } \\
\text { inhibiton } \\
\text { \% }\end{array}$ & $\begin{array}{c}\text { Inhibitory } \\
\text { effect 0f } \\
\text { browning \% }\end{array}$ & $\begin{array}{c}\text { Tyrosinase } \\
\text { inhibiton } \\
\text { \% }\end{array}$ & $\begin{array}{c}\text { Inhibitory } \\
\text { effect 0f } \\
\text { browning \% }\end{array}$ & $\begin{array}{c}\text { Tyrosinase } \\
\text { inhibiton } \\
\text { \% }\end{array}$ \\
\hline 0 & 15.2 & 47.5 & 14.2 & 17.5 & 18 & 17 \\
\hline 15 & 16.6 & 55.5 & 16.6 & 34.5 & 20.1 & 49.1 \\
\hline 30 & 19.4 & 69.3 & 18 & 47.9 & 23.7 & 70 \\
\hline 45 & 21.8 & 78.2 & 20.1 & 53.8 & 27.2 & 47.3 \\
\hline 60 & 23.7 & 88 & 22.3 & 55.5 & 28.1 & 47.3 \\
\hline 90 & 25.8 & 100 & 25.1 & 100 & 30.7 & 69.2 \\
\hline 120 & 27.9 & 100 & 29.3 & 100 & 33.6 & 100 \\
\hline
\end{tabular}




\section{The inhibition Mode of tyrosinase by melatonin:}

The inhibition mode was studied by using melatonin. Figure 8 explains the kinetic results as double reciprocal Lineweaver-Burk plots for melatonin $(5.9 \mathrm{mM})$. The nature of the inhibition was noncompetitive. The $\mathrm{K}_{m}$ value was $(1.96 \mathrm{mM})$ calculated for melatonin that remained constant, while $\mathrm{V}_{\max }$ was reduced from 228.13 to $114.06 \mathrm{U}^{\mathrm{ml}}{ }^{-1} \cdot \mathrm{min}^{-1}$. Inhibition constant $\mathrm{K}_{i}$ value was $6.9 \mathrm{mM}$. Prior inhibition studies demonstrated that GSH is noncompetitive inhibitor of apple juice PPO respectively (31). Mushroom tyrosinase was noncompetitively inhibited by cinnamic acid with $K_{i} 1.994 \mathrm{mM}$ (41). On the othor hand, Paudel and other (2019)(42) reported competitively inhibition of tyrosinase by bromophenol.

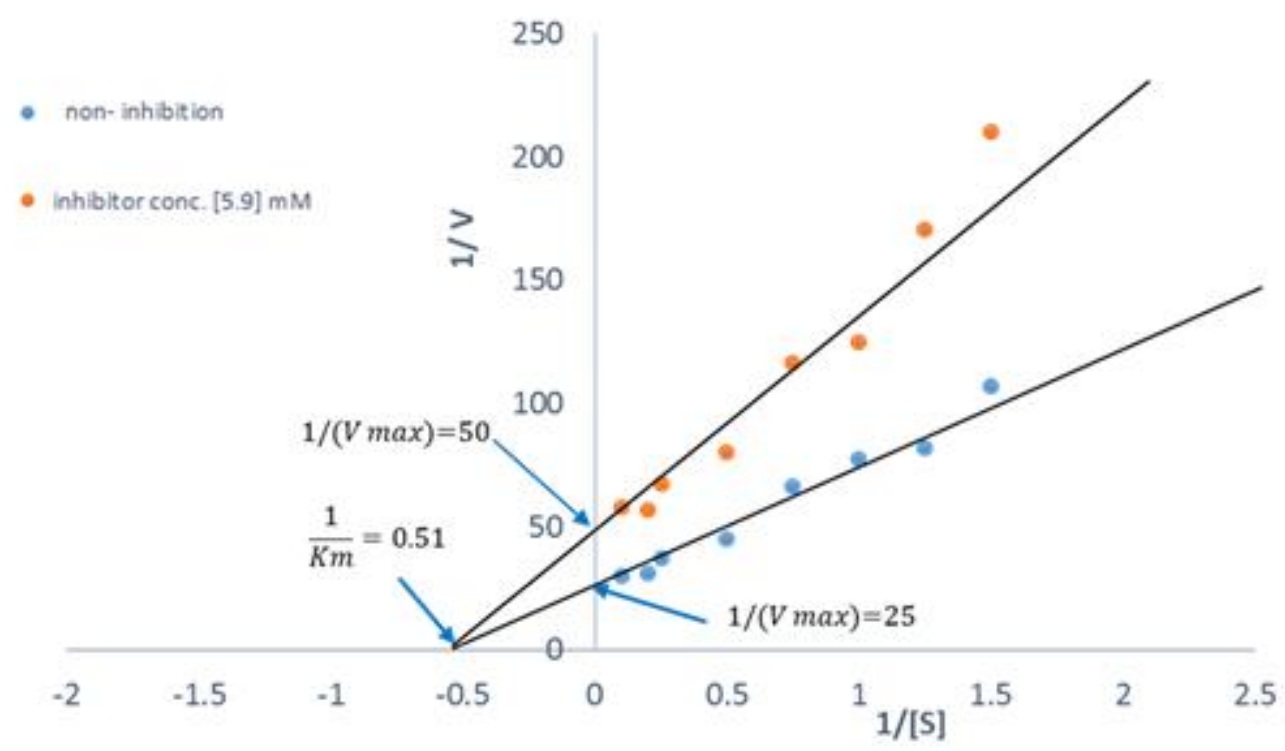

Figure 8. Lineweaver-Burk plot of inhibition of purified Tyrosinase by melatonin

\section{Changes in UV $\lambda_{\text {max }}\left(A_{U v}{ }_{2294}\right)$ and browning intensity (A420)}

Maillard reaction is related with improvement of UV-absorbing intermediate complexes, before brown pigments generation. Several intermediate products may convert to ending brown complexes, but others intermediate products are still during heating. Ajandouz and others (2011)(43) indicate that the Auv ${ }_{2294}$ and browning intensity $\left(\mathrm{A}_{420}\right)$ are reflected of intermediate and browning compounds respectively. A gradual increasing in $\mathrm{AUV}_{\lambda \max }$ was found with increasing heating time for untreated quince juice as depicted in (Figure 1). These results accord to increment in absorbance at $294 \mathrm{~nm}$ for glucose-glycine and chitosan -glucose mixtures with heat treatment (44-45) 


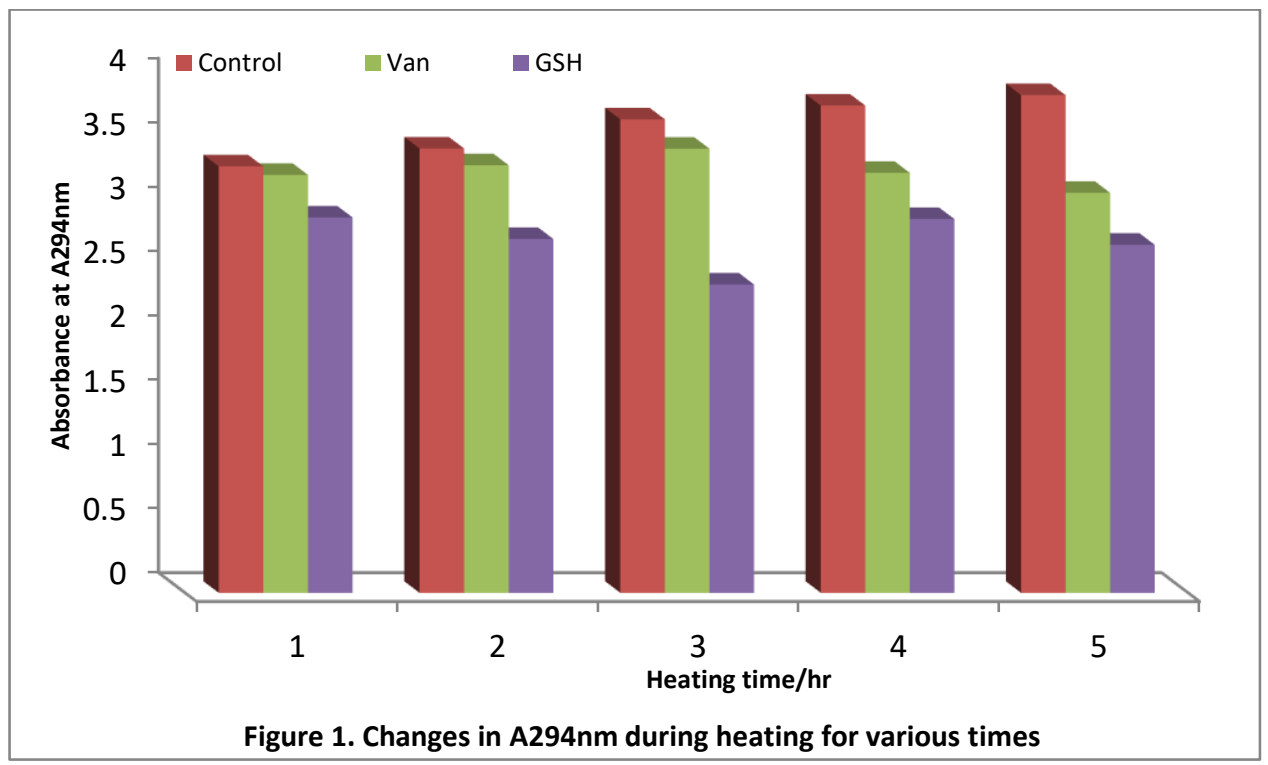

Browning intensity $\left(\mathrm{A}_{420}\right)$ of control proportionally increased by heating time (Figure 2). Browning intensity $\left(\mathrm{A}_{420}\right)$ increasing for numerous model systems depending on sugar natures, intermediates and coloured polymers which are resulted (46). The decreasing of Auv imax and browning intensity by treating with vanillin and glutathione was observed compared to control (Figure1 and 2).

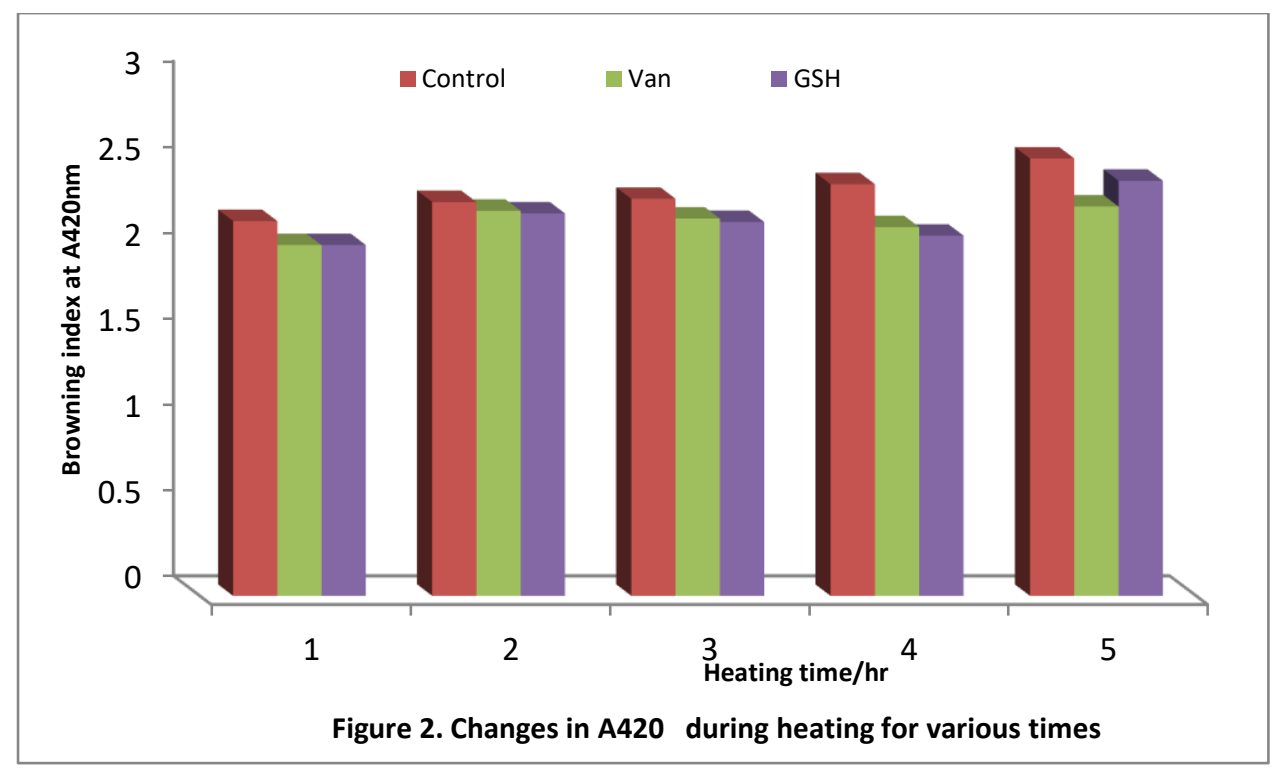




\section{Changes in reducing sugar and free amino group content:}

A reducing sugar and free amino acid contents of heated quince juice, are revealed in Figure 3 and 4. A markedly lower in reducing sugar but gradually in free amino group was found when heated to $5 \mathrm{~h}$ respectively. The lower in reducing sugar during heating of lysine-fructose, casein-glucose and chitosan-glucose systems was described $(39,47,48)$. A continuous reduction in the amino group content was seen as the heating time increased (45). Treated quince juice with vanillin revealed an increase in the reducing sugar, whereas the decrease was observed with glutathione with increasing heating time compared to control (Figure 3).

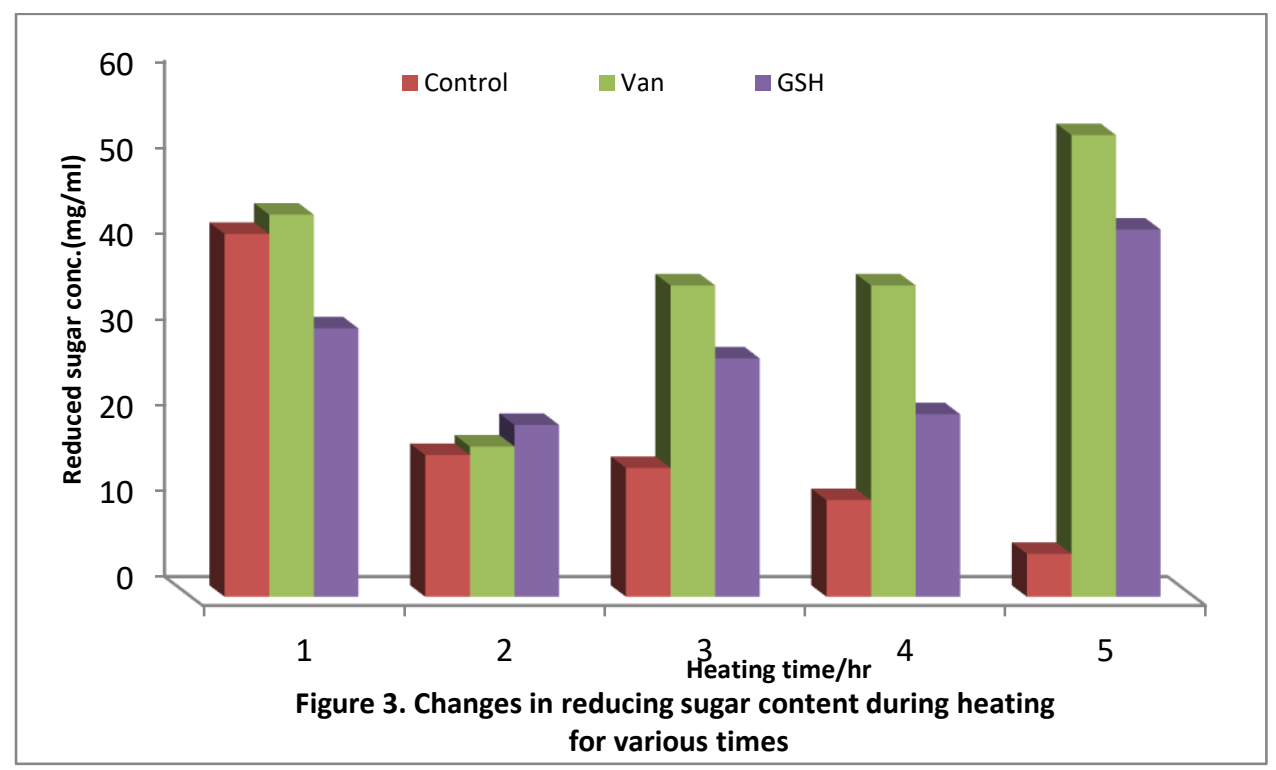

The results indicated the participation of the amino group and carbonyl group of sugar in the development of MRPs during heat treatment, as confirmed by the lower free amino groups and reducing sugars remaining upon heat treatment. Conversely to the reduced sugar, after treating of quince juice with vanillin the free amino acid content was diminished, while increased with glutathione treatment with increasing heating time compared to control (Figure 4). 


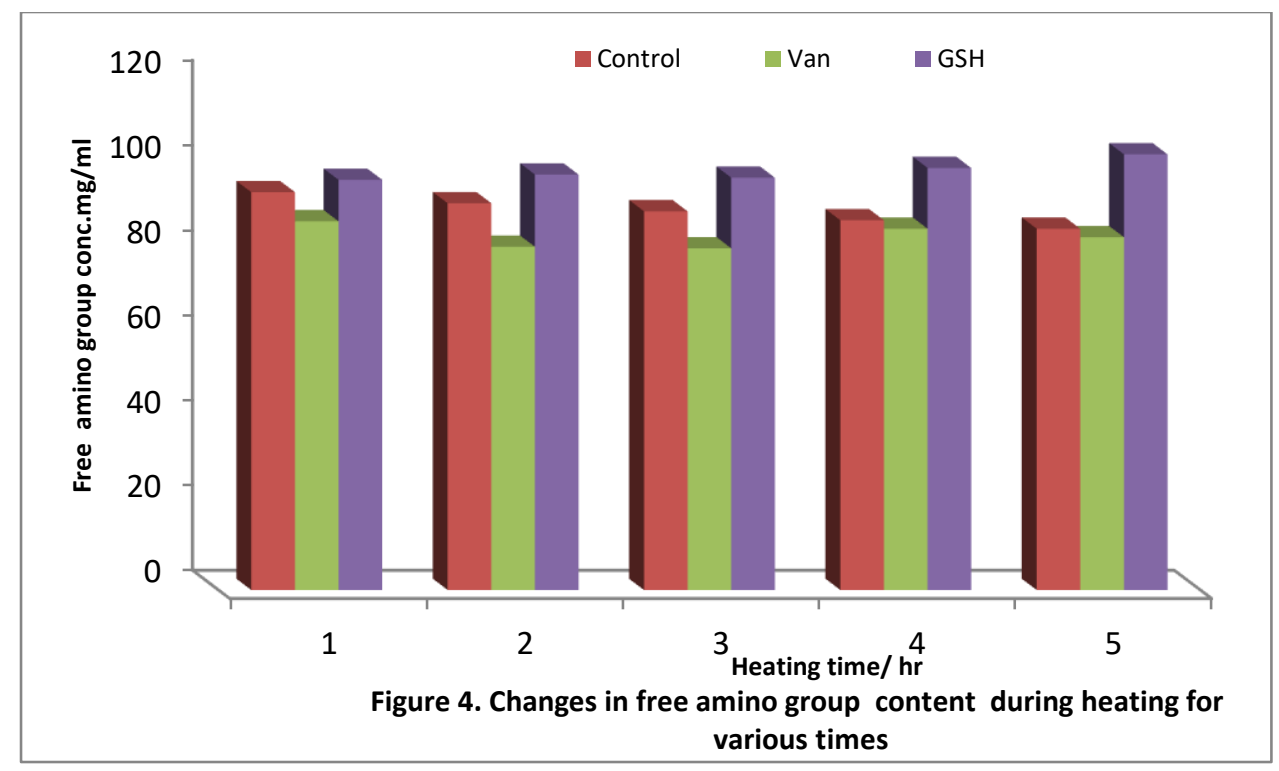

The decrease in reducing sugar and free amino acid was in agreement with increment of Auvimax and browning intensity. This indicated that long heating catalyzed the interaction between amino groups, and reducing sugar through glycation process. The reaction rate of glycation was influenced by carbonyl electrophilicity (49-50).

\section{Changes in phenolic content:}

Phenolic constituents in the presence of oxygen in many edible plant products such as fresh fruits and vegetables were oxidized by polyphenol oxidases (PPO) or tyrosinases to produce o-quinones. The polymerization of o-quinones into complex brown pigments takes place in occurrence of amino acids and proteins (51). Furthermore, quinones formed in the initial browning reaction can contribute in coupled oxidation reactions, allowing them to oxidize additional polyphenols that cannot be directly enzymatically oxidized.

The results exhibit the decrease in phenolic content with increasing heating time. Treating the juice with vanillin and glutathione, phenolic content were increased and reduced compared to control respectively (Figure 5). 


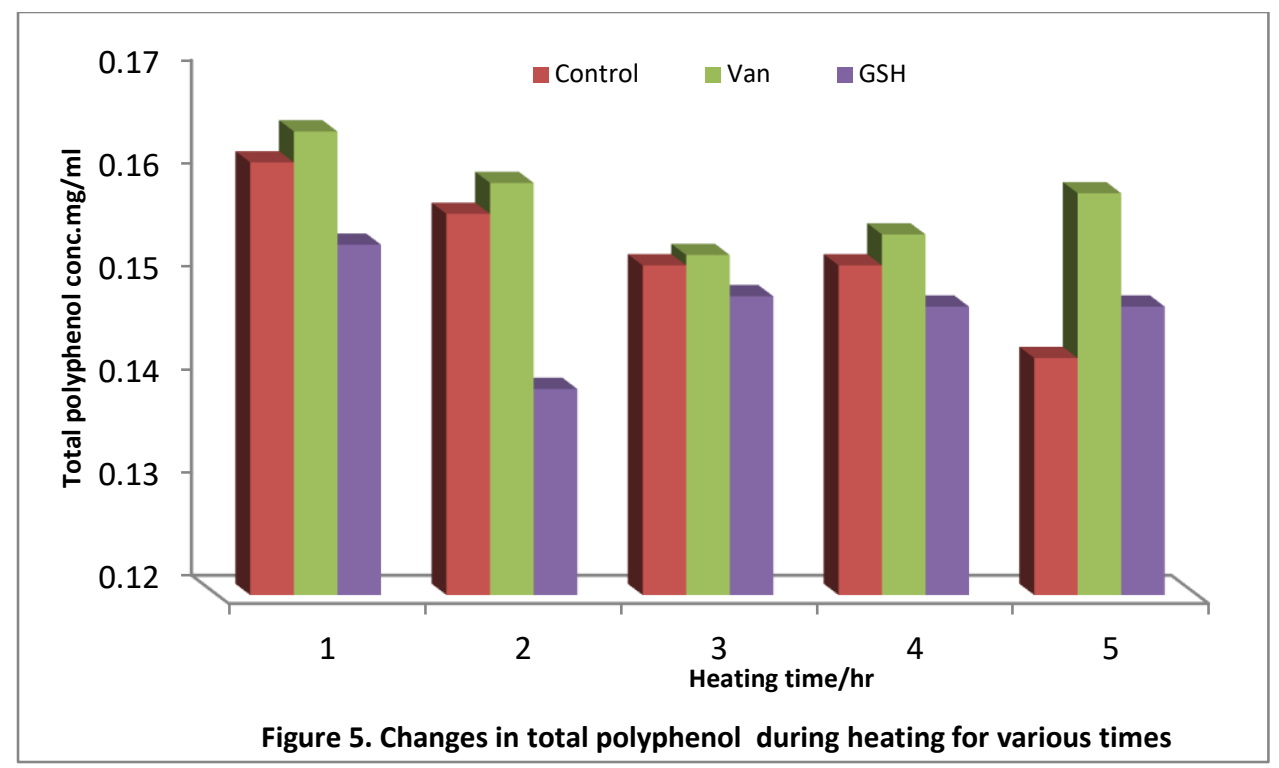

\section{Changes in reducing power:}

Figure 6 shows a proportionally slow increase in reducing power to end of heating time. Both vanillin and glutathione treatment were higher than control in reducing power absorbance. With increasing heating time, the reducing power of glucose-glycine (52), xylose-lysine (53) and glucose-lysine mixtures (52) was reported increased.

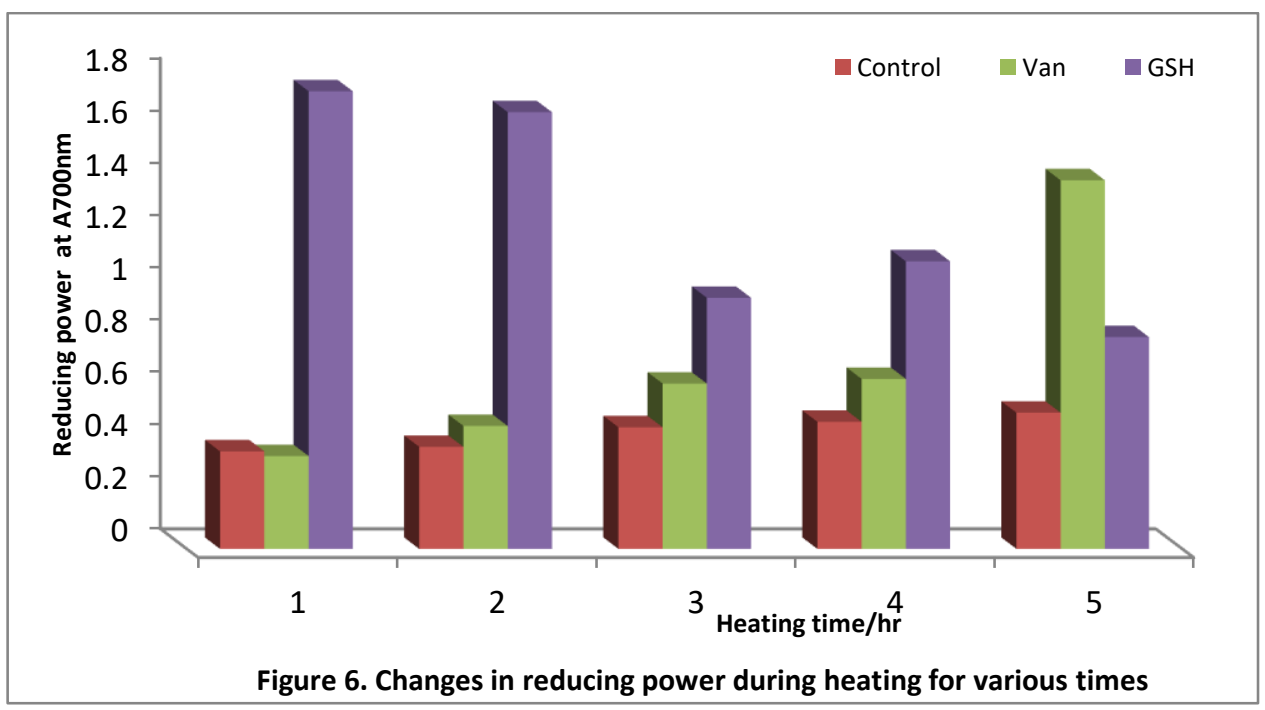




\section{Changes in Inhibition of lipid peroxidation percentage:}

Lipid peroxidation can be defined commonly as a process under which oxidants such as free radicals attack lipid containing unsaturated carbon-carbon bond to yield fatty acid hydroperoxide in presence of oxygen molecule. The unstable hydroperoxides is degraded easily to shorter chain hydrocarbons as aldehydes (45). The results in figure 7 shows the increasing inhibition of lipid peroxidation percentage evidently in the first hour of heating time and then decreased gradually with increasing heating time. Also that inhibition of lipid peroxidation percentage was incremented when treating the juice with vanillin, but it was decreased when treating it with glutathione compared to control.

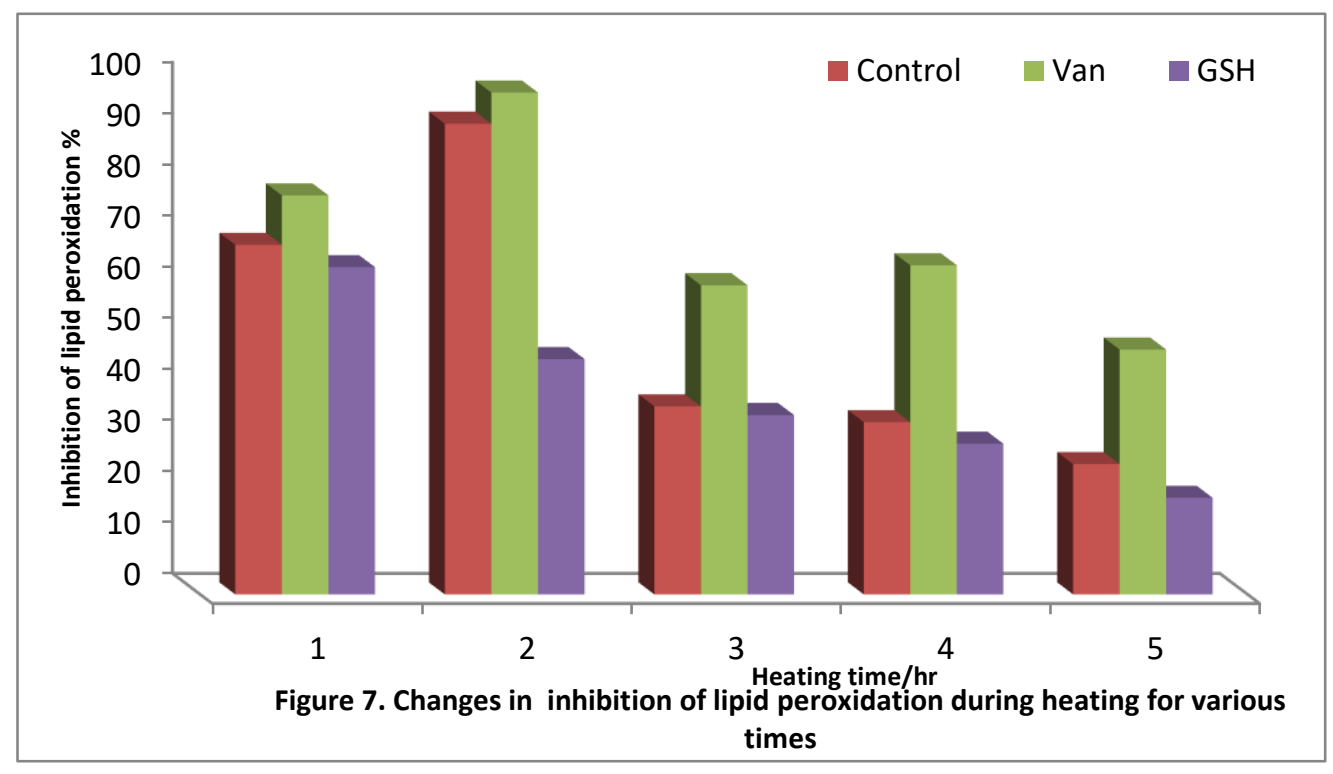

Various efforts have been completed to control Maillard reactions in foods. For example, adding natural or artificial compounds to Maillard reactions eliminate one of the reactants, addition compounds, as $\mathrm{N}$-acetylcysteine which inhibits reactions or generates colorless products (54-55), trapping of $\alpha$-dicarbonyl compounds by activating hydroxyl-containing compounds, such as gallic acid (56-58). In addition to the Maillard inhibition has been effectively attained via modification of amines residues by acetylation shield lysine from further modification.(59).

Generally, browning initiation was prevented by antioxidants which react with oxygen. Antioxidants compounds also react with the intermediate products, thus breaking the chain reaction and melanin formation was prevented (60). 


\section{Conclusion:}

The antioxidant properties of vanillin, glutathion and melatonin can contribute in controlling the millard reaction and inhibition of tyrosinase. Adding these compounds to foods during processing and storage may be beneficial for improving manufacture of fruit and vegetable. In some plant sources, these compounds have occurred as natural compounds, therefore more accepted as food ingredients than synthetically manufactured compounds.

\section{Acknowledgement:}

The authors are grateful to those who provide facilities to achieve this work. Special thanks for the Department of Chemistry, College of Education for Pure Science, University of Mosul.

\section{References}

1- (Silva B. M., Andrade P. B., Martins R. C., Valentao P., Ferreres F., Seabra R. M. and Ferreira M., Journal of Agriculture and Food Chemistry, 53: 111-122(2005)).

2- (Kumari A., Dhaliwal Y.S., Sandal A. and Badyal J., Indian Journal of Agricultural Biochemistry, $26,61-65(2013))$.

3- (Sharma R., Joshi VK. and Rana C., Ind J Nat Prod Resour., 2:354-357(2011)).

4- (Shinomiya F., Hamauzu Y. and Kawahara T., Biosci. Biotechnol. Biochem., 73:17731778(2009)).

5- (Rodriguez - Guisado I., Hernandez F., Melgarejo P., Legua P., Martinez R. and Martinez J. J., Sci. Hortic., 122:491 -496(2009)).

6- (Przemysław J. S., Picazo S. M., Szumny A., Carbonell - Barrachina A. A., and Hernandez F., J. Scientia Horticulturae, 165: 163-170(2014)).

7- (Hamauzu Y., Inno T., Kume C., Irie M. and Hiramatsu K. J. Agr. Food Chem., 54: 765772(2006)).

8- (Silva B. M., Casel S., Andrade P. B., Seabra R. M., Oliveira M.B. and Ferreira M. A., Journal of Agricultural and Food Chemistry, 52 (5):1201-1206(2004)).

9- (Hamid R. G. and Khadijeh. H. A., ActaSci. Pol., Technol. Aliment., 13 (2):129 - 134(2014)).

10- (Duke J.A., Bogenschutz M.J., du Cellier J., Duke P.A.K.,. Handbook of medicinal herbs. 2nd Edition, CRC. p 650(2002)).

11- (Hilgert N.I., Journal of Ethnopharmacology, 76:11-34(2001)).

12- (Siddiqui T.A., Zafar S. and Iqbal, N., Journal of Ethnopharmacology, 83:13-17. (2002)).

13- (Koutb M. and Morsy FM., J Adv Lab Res Biol., 3:36-41 (2012)). 
14- (Légua P., Serrano M., Melgarejo P., Valero D., Martinez J.J., Martinez R. and Hernãndez F., Sci Hortic., 154:61-65 (2013)).

15- (Szychowski P.J., Munera-Picazo S., Szumny A., Carbonell-Barrachina A.A. and Hernández F., ,Sci Hortic., 165:163-170 (2014)).

16- (Wojdyło A., Teleszko M. and Oszmian'ski J., Food Chem.,152:261-270 (2014)).

17- (Echavarría A.P., Torras C., Pagán J. and Ibarz A., Food Engineering Review 3: 136-158 (2011)).

18- (Tamanna N. and Mahmood N., International Journal of Food Science Volume, 6(2015)).

19- (Hellwig M. and Henle T., Angew. Chem., Int. Ed. 53:10316-10329(2014)).

20- (Manzocco L., Nicoli M., Mastrocola D., Calligaris S. and Lerici C., Science and Technology, 11: 340-346. (2011)).

21- (Corzo-Martínez M., Corzo N., Villamiel M., del Castillo M.D., "Food Biochemistry and Food Processing". 2nd Ed. Ames, Wiley \& Sons: 56-71(2012)).

22- (Wrolstad R.E., "Food Carbohydrate Chemistry". USA, Wiley \& Sons: 50-72 (2012)).

23- (Jaeger H., Janositz A. and Knorr D., Pathologie Biologie., 58(3): 207-13(2010)).

24- (Lund M. N. and Ray C.A., J. Agric. Food Chem., 65:4537-4552(2017)).

25- Davídek J. Velíšek J. and Pokorný J. (Editors). Elsiver Science Publishers,Amsterdam, the Netherlands(1990)).

26- (Nafisi K. and Markakis P., J. Agric. Food Chem., 31:1115(1983)).

27- (Brownlee M., Vlassara H., Kooney A., Ulrich P. and Cerami A., Science, 232 (4758):1629-1632(1986)).

28- (Hirsch J., Petrakova E. and Feather M. S., Res., , 232:125-130(1992)).

29- (Chen H.J. C. and Cerami A. J., Carbohydr. Chem., 12 (6): 731-742(1993)).

30- (Gacche R.N., Warangkar S.C. and Ghole V.S., Journal of Enzyme Inhibition and Medicinal Chemistry, 19 (2):175-179 (2004)).

31- (Decker A. L."Worthington Enzyme Manual, Polyphenol oxidase". Worthington Biochemical Corporation, 39-40 (1977)).

32- (Bugg T.. “An Introduction to enzyme and coenzyme chemistry”, Blackwell Science Ltd(1997)).

33-(Tsai J.P., Yu Y.T., Chen H.S., Liu C.C. and Sun Y.F., Food Research International 42: 380-386 (2009)).

34- Garriga M., Almaraz M. and Marchiaro A., Actas de Ingeniería, 3: 173-179 (2017)).

35- Robyt F.J. and White J.B. "Biochemical techniques ,theory and Practice". Brookes/Cole publishing company, Monterey, California, (2001)). 
36- (Anesini C., Ferraro G.E. and Filip R., J. Agric. Food Chem., 56(19): 9225- 9229 (2008)).

37- (Matmaroh K., Benjakul S. and Tanaka, M., Food Chemistry, 98: 1-8(2006)).

38- (Yi O.S., Meyer A.S. and Frankel E.N., Journal of American Oil and Society, 74: 13011307(1997)).

39- Gu F., Kim M.J., Feng B., Xia S., Hayat K. and Zhang X., Food Chemistry, 117: 48-54(2009)).

40- (Lim W.Y. and Wong C.W., J. Food Sci. Technol.,55(8):3001-3007(2018)).

41- (Shia Y., Chen QX., Wang Q., Song KK. and Qiu L. Food Chemistry, 92:707-12(2005)).

42- (Paudel P., Wagle A., Seong S.H., Park H.J., Jung H.A. and Choi J.S., Mar. Drugs,17( 295):114(2019)).

43- (Ajandouz E.H., Tchiakpe L.S., Ore F.D., Benajiba A. and Puigserver A. Journal of Food Science 66: 926-931(2011)).

44- (Chang L.H., Chen C.Y. and Tan F.J. Food Chemistry, 124: 589-595(2011)).

45- (Phisut N. and Jiraporn B., Inter. Food Res.J., 20(3): 1077-1085 (2013)).

46- (Van Boekel M.A. Food Chemistry, 62: 403-414(1998)).

47- (Rao S.M., Chawla P.S., Chander R. and Sharma A. Carbohydrate Polymer, 83: 714-719(2011)).

48- (Zeng Y., Zhang X., Guan Y. and Sun Y. Journal of Food Science 76: 398-403(2011)).

49- (Naranjo G.B., Malec L.S. and Vigo M.S. Food Chemistry, 62: 309-313(1998)).

50- (Bunn, H.F. and Higgins, P.J. Science, 213: 222-224(1981)).

51- (Grotheer P., Marshall M. and Simonne A. "Sulfites: Separating fact from fiction". U.S. Department of Agriculture, UF/IFAS Extension Service, University of Florida, pp. 1-5(2005)).

52- (Yoshimura Y., Iijima T., Watanabe T. and Nakazawa H. Journal of Agricultural and Food Chemistry, 45: 4106-4109(1997)).

53- Kim S.J. and Lee S.Y. Food Chemistry, 116: 227-232( 2009)). 
54- (Ames, J. M., Trends Food Sci. Technol., 1:150-154(1990)).

55- (Friedman M. J., Agric. Food Chem., 44 (3):631-653(1996)).

56- (Navarro M. and Morales F.J., Eur. Food Res.Technol., 242: 1101-1110(2016)).

57- (Wu C.H., Huag S.M., Lin J.A. and Yen G.C., Food Funct., 2:224-234(2011)).

58- (Lo C.Y., Hsiao W.T. and Chen X.Y. J., Food Sci., 76 (3): 90-96(2011)).

59- (Lakkis J. and Villota R., Food Chem., 43: 93-105(1992)).

60- (Lindley M.G.,Trends in Food Science \& Technology, 9(8-9):336-340 (1998). 